\title{
ESTUDOS DE RECEPÇÃO PARA A CRÍTICA DA COMUNICAÇÃO
}

\section{Estudos de Recepção propõem uma abordagem diferenciada dos meios de comunicação, vendo-os no processo de interação social}

Pensar a comunicação a partir da recepção permite-nos entender melhor o papel dos meios de comunicação na vida da sociedade contemporânea, como eles atuam no cotidiano dos grupos sociais, nas diferentes comunidades e culturas. Permite-nos também sair da oposição emissor todo-poderoso versus receptor passivo ou, por outro lado, emissor neutro versus receptor/consumidor todo-poderoso.

Essas posturas têm se reproduzido de maneira muito interessante, por exemplo, no discurso dos jovens estudantes de Comunicação. Num primeiro momento, é comum ouvi-los criticar ferrenhamente, a partir do senso comum, o poder dos meios de comunicação, ou seja, a mídia deturpa, aliena etc. Feita a crítica, vem a prostração: diante dessa realidade nada mais lhes resta senão assimilar os tais procedimentos técnicos de produção com as mesmas características criticadas, abandonando completamente a perspectiva crítica que adotavam e passando então a incorporar a postura hegemônica na edição de suas peças publicitárias, de seus filmes, enfim de todos os produtos culturais que sua profissão lhes permitirá executar.

Vivi essa experiência muitas vezes e costumo dizer que eles, os alunos, têm a capacidade de ser, utilizando os termos de Umberto $\mathrm{Eco}^{1}$, apocalípticos e integrados ao mesmo tempo. Parece paradoxal, mas não é.
Essa postura revela-se com uma força cuja conseqüência é a continuidade do status quo, a perda da perspectiva da mudança resultante de um conjunto de atitudes que devem ser tomadas e assumidas pelo profissional verdadeiramente crítico. Ou seja, ela exime o sujeito de qualquer responsabilidade por aquilo que está fazendo, forma o futuro comunicador compromissado apenas com os interesses do mercado, sem qualquer noção de responsabilidade com a sociedade civil.

Pensar a comunicação a partir da recepção possibilita-nos, no campo comunicação/ educação, tentar desconstruir tal discurso, buscando compreender o processo de comunicação como interação social.

\section{COMUNICAÇÃO VERSUS TRANSMISS ̃̃O DE INFORMAÇÕES}

Para colocarmos essa discussão no seu devido lugar temos de retomar, mesmo que rapidamente, a crítica à idéia de comunicação

A AUTORA
Roseli Fígaro
Professora da Faculdade de Comunicação da Funda-
ção Armando Álvares Penteado - FAAP. Doutora em
Comunicação pela ECA-USP. Editora de Comunica-
cão \& Educação.


apenas como transmissão de informações. Essa é uma postura que ganha força na virada do século XIX para o XX com a ideologia do progresso linear da sociedade, a partir apenas do desenvolvimento tecnológico. A Teoria Matemática da Comunicação ${ }^{2}$, importante avanço científico para a invenção de novas máquinas, computadores, da inteligência artificial, passa a ser apropriada para pensar as relações humanas, as relações sociais, e impulsiona então uma corrente de pensamento, ainda hoje hegemônica, que pensa a sociedade, e portanto a comunicação, como uma relação similar à transmissão de informações de uma máquina para outra, com todo o determinismo que tal postura acarreta.

A eficácia do esquema informacional ${ }^{3}$ para explicar a transmissão de informações entre emissor e receptor foi de tal maneira naturalizada que passou a ser adotada tanto pelos críticos ${ }^{4}$ quanto pelos funcionalistas ${ }^{5}$.

Os estudos de recepção vêm no sentido de procurar desconstruir esse pensamento, adotando uma abordagem diferenciada do que seja a comunicação, extrapolando sua explicação como transmissão linear de informação, baseada no reflexo, ainda muito apoiada numa compreensão da Psicologia Behaviorista $^{6}$, comportamental, para problematizá-la como um fenômeno sociológico e cultural.

Ressaltamos esse aspecto da discussão porque é assim que hegemonicamente a comunicação é abordada ainda hoje.
Se analisarmos todo o fetiche, toda a mística que há em torno das tecnologias vamos observar ainda que elas nos são apresentadas como a possibilidade mágica de resolução de todos os problemas da contemporaneidade: a democratização, a liberdade de acesso etc. Como se essas tecnologias falassem por si mesmas, autonomizando-se do corpo ideológico, político, econômico, cultural do conjunto que é a sociedade. Como se essas máquinas não fossem projetadas, programadas e acionadas por pessoas que pensam e programam as estratégias de seu uso, que representam empresas, institutos científicos que, a partir de determinados objetivos, elaboram os discursos dos quais essas máquinas fazem parte.

Essas idéias, que, assim enunciadas, parecem tão claras e tão obviamente refutáveis, têm construções bastante elaboradas. Inclusive um autor que respeitamos bastante, Pierre Lévy, chamou nossa atenção num artigo para Folha de $\mathrm{S}$. Paulo, em 1998, com o título Revolução virtual. A cibercultura é hoje herdeira legítima das idéias progressistas do Iluminismo. No citado artigo, o autor alerta para uma nova era tecnológica que permitiria a todo mundo desenvolver novos acessos, pois os meios de comunicação nos remeteriam a um momento pleno, onde os ideais do Iluminismo, ou seja, os ideais de liberdade, fraternidade e igualdade, seriam retomados como o manifesto da cibercultura. Se fecharmos os o-

2. É basicamente uma teoria sobre o rendimento ótimo da transmissão das mensagens, criada por engenheiros de telecomunicações na década de 20.

3. O esquema informacional foi proposto por C. Shannon, engenheiro da Bell System, em 1949, e trata da passagem do sinal (mensagem) da fonte de informação para o transmissor e daí para um canal. Do canal, o sinal é captado por um receptor que decodifica a mensagem para o destinatário.

4. São chamados de críticos os teóricos da comunicação da Escola de Frankfurt: Theodor Adorno, Max Horkheimer, Walter Benjamim entre outros. Ver mais sobre o assunto: MATTELART, Armand. História das teorias de comunicação. São Paulo: Loyola, 1998. 5. A escola funcionalista, de origem norte-americana, teve como seus fundadores H. Lasswell, P. Lazarsfeld, entre outros. Ver mais sobre o assunto: MATTELART, Armand. História... op.cit.

6. Essa corrente da Psicologia defende que se podem estudar os conteúdos psicológicos através das suas manifestações observáveis, colocando o comportamento humano como representação da adaptação do homem ao ambiente, que pode ser decomposto em seqüências explícitas: o estímulo, a resposta, o reforço. 
lhos para a realidade, podemos assinar embaixo do que ele diz, mas, se sairmos à rua de olhos abertos para enxergar a realidade, temos de pôr vários pontos de interrogação nesse tipo de discurso, porque sabemos da diversidade que é a nossa realidade. Essa é a teologia que se faz das técnicas, da tecnologia. No entanto, isso não quer dizer que tenhamos de jogar o computador pela janela ou fazer a mesma coisa com a televisão. Não sejamos nem apocalípticos nem integrados, nem naturalizemos todos esses novos meios e, principalmente, as formas pelas quais eles nos chegam, nem mesmo partamos para a crítica, uma crítica por si mesma, que não leva a lugar nenhum.

Então qual é a postura que podemos adotar para pensar esse processo de comunicação?

Temos de resgatar a cultura, a idéia de sujeito. Se não retomarmos a idéia de relações sociais, o conceito de cultura e mesmo o conceito do que é o sujeito não conseguiremos pensar no processo de comunicação.

Para fazer a crítica, precisamos desvendar, desconstruir, mostrar como essas linguagens são construídas, dar a conhecer, tornar a informação conhecimento ${ }^{7}$. A experiência, essa é a maior qualificação que podemos ter para estarmos antenados ou aptos à leitura dos diferentes discursos que são construídos, as diferentes formas, maneiras de se editar a realidade. Sem pensar a comunicação como processo de inter-relação não poderemos entender o que se passa na atualidade, principalmente devido à velocidade com que nos chegam todos os símbolos que circulam na sociedade, e atuar e/ou transformar a realidade.

A escola pode recuperar seu lugar de importância nessa discussão. Para isso, temos de retomar o conhecimento e a formação humanística que ela já nos forneceu para re- pensar esse processo e a forma como temos abordado os meios de comunicação - como todo-poderosos em relação a sujeitos passivos, absolutamente passivos, sem nenhum poder sobre eles.

\section{DEMOCRATIZAÇÃO DOS MEIOS}

Mas podemos questionar de fato empresas poderosas, como a Rede Globo ou a Folha de S. Paulo? A resposta é afirmativa.

Esse poder tem de ser questionado via democratização da posse dos meios de comunicação, via participação das comunidades na elaboração das políticas e da legislação que regulam a concessão e a posse dos meios de comunicação, não só discutindo sobre o direito das comunidades ao espaço da radiodifusão, mas sobretudo questionando qual é o compromisso legal das empresas com a sociedade civil ao utilizarem um serviço público.

Pouco preparo existe e pouca importância se dá para essa discussão concreta, objetiva. É difícil encontrá-la nas salas de aula. Sem questionar a concentração do poder econômico, ou seja, o porquê de sete ou oito grandes empresas transnacionais no mundo mandarem em tudo o que se produz em termos de difusão cultural, desde as artes plásticas até CDs e novelas, não podemos pensar em ampla liberdade de expressão.

Na sociedade contemporânea, eminentemente tecnológica, todas as informações, da simples ligação telefônica à transmissão de sinais para o vídeo, são transmitidas através das telecomunicações. Como, 
então, nesse jogo de forças entre os mercados e os blocos econômicos, abrir mão da posse do controle de empresas que trabalham com essas tecnologias? A resposta a essa pergunta foi dada, por exemplo, pelo pequeno interesse demonstrado na privatização do sistema Telebrás. Ou seja, é aí que as coisas começam. Pensar no poder de manipulação da linguagem, do gênero telenovela ou de qualquer outro produto cultural como se fosse a origem de todo o problema apenas desvia o foco da questão principal. Precisamos começar a focar as coisas onde elas precisam ser focadas, essa é a questão.

Para clarear um pouco mais essa discussão, concentremo-nos agora no problema das empresas de mídia enquanto produtoras. Aí a importância dos estudos de recepção em entender que os produtos culturais, resultantes de uma série de contradições que se instalam dentro das próprias empresas de comunicação que os produziram, são polissêmicos.

Estas não têm, necessariamente, um discurso homogêneo, porque também existem as contradições dentro do próprio meio. Se continuarmos a pensar em termos de telenovela, produto cultural de maior penetração no Brasil, podemos citar a experiência do início dos anos 70 , período mais duro da ditadura militar, quando dramaturgos como Lauro César Muniz, Benedito Ruy Barbosa, Dias Gomes foram para a Rede Globo. A censura os impedia de produzir para o teatro e eles passaram a escrever telenovelas, e, dentro do espaço que possuíam, questionavam o que a própria ditadura estava fazendo. Tentaram e conseguiram criar uma nova linguagem para a telenovela, muitas vezes questionando, por meio de metáforas, o momento político.
É preciso entender os meios de comunicação a partir das mediações. Eles são mediadores entre nós e a realidade. Mas não só eles. Temos os grupos sociais, temos o nosso cotidiano concreto, real, vividos como outros mediadores, porque não existe só a televisão ou o jornal ou o rádio, nessa composição do que seja a realidade. Recebemos a todo momento uma série de discursos sociais, e eles estão aí se cruzando, se batendo, e é a partir deles que formamos nosso ponto de vista, que podemos ser mais ou menos críticos.

O discurso da religião, o discurso do poder dos partidos, o discurso da família, da escola, eles estão aí, não são só os meios de comunicação. Eles não passaram a existir a partir do momento que se usou a televisão. Sem dúvida, eles foram ampliados, estilizados, criaram uma outra linguagem, outra forma. Mudaram de roupa. Agora a mídia está fazendo também a mediação desses discursos.

\section{ESCOLA COMO MEDIADORA}

Mas nós, enquanto professores, também somos mediadores, também constituímos e podemos ter o poder de constituir, de dar ao discurso escolar essa força de ser um mediador diferenciado, porque nele há potencial para isso. O professor está a todo momento recebendo o retorno do seu discurso e vê quanto é diferente esse retorno. Se tem alguém que no seu dia-a-dia recebe essa multiplicidade de uma forma ampla, somos nós, no nosso cotidiano profissional, talvez até muito mais que o jornalista, porque o jornalista está lá sob uma pauta, sob uma chefia, sob um discurso, digamos, hegemônico, ao qual tem de responder. Os professores também são representantes do discurso da instituição escolar, mas as contradições, a diversidade de realidades que vem do aluno, estão muito mais próximas. 
Valorizar isso é atuar para podermos ser um pólo importante de mediação. A escola pode recuperar seu papel de importante mediadora social, principalmente em relação aos meios de comunicação. E não é jogando fora esse discurso da mídia, nãoé ignorando sua força que conseguiremos atuar como mediação na formação de um ponto de vista crítico.

Temos de questionar nossa prática em geral e, para fazê-lo, devemos abandonar o discurso pouco proveitoso de ou sacramentar a mídia como ótima e trazê-la para a sala de aula sem nenhum senso crítico, isto é, sem vinculá-la à realidade mais geral da sociedade, usando-a apenas como instrumento, como ferramenta, ou, ao contrário, não levar nada disso para a sala de aula, baseados na prerrogativa de que os meios de comunicação são instrumentos de alienação.

É preciso ampliar o campo de visão. Ver os meios de comunicação também como produtos do trabalho social. Por isso uma outra discussão que se faz necessária na atualidade é sobre a categoria trabalho; pois é ela a categoria norteadora do que acontece no mundo contemporâneo, apesar de todos os discursos contrários ao reconhecimento disso. Nós construímos e somos construídos no processo cultural. Somos produtores de cultura e somos produtos da cultura. É pensando num sujeito assim, é pensando num sujeito com essa responsabilidade, é resgatando esse papel do sujeito que podemos ter uma visão crítica de fato para compreender como são construídos os discursos veiculados pelos meios de comunicação.

Recentemente, estudando o mundo do trabalho ${ }^{8}$, a fábrica, o chão de fábrica, percebi quão importantes eles são como mediadores na construção dos significados que os metalúrgicos dão às informações, às mensagens que recebem dos meios de comunicação. Descobri que, entre os meios de comunicação mais importantes para os trabalhadores saberem dos problemas, das informações úteis para o seu dia-a-dia, estão seus colegas de trabalho. Apesar de todo o discurso em contrário, as relações interpessoais são muito importantes. No confronto de pontos de vista expressos pelos diferentes mediadores é que se confirmam ou se repudiam os discursos. Estes são concluídos, concertados dentro dos grupos sociais. Não é só a dona-de-casa que conclui e confirma o que ela entendeu da telenovela nas suas discussões na feira, no mercado ou no portão, com alguma amiga. $\mathrm{O}$ mesmo se passa com qualquer trabalhador quando se encontra com os amigos. No caso dos jovens, conhecer uma nova música e saber tudo a respeito dela, por exemplo, não é para uso próprio diletante, mas para relacionar-se com seu grupo, pois é nesse espaço social que esse significado se completa, que os signos têm sentido. Então é lá que temos de atuar.

A minha preocupação, nesse sentido, é buscar a reflexão para mostrar o quanto a escola, espaço da educação, pode estar sendo importante para a construção dos valores sociais. Esse estreitamento entre comunicação e educação nos permite repensar se estamos dispondo dos instrumentais analíticos e teóricos adequados para a nossa prática diária enquanto comunicadores e educadores. Temos procurado discutir como resgatar a crítica, deixando de lado as posturas maniqueístas. Estou certa de que, para retomarmos a crítica, precisamos resgatar o papel do sujeito e a importância da cultura, entendendo a comunicação como processo de inter-relação social para podermos compreender melhor o momento que estamos vivendo. Os estudos de recepção têm muito a contribuir para isso. 
Resumo: A autora propõe pensar a comunicação a partir da recepção para entender melhor o papel dos meios de comunicação na vida da sociedade contemporânea, como eles atuam no cotidiano dos grupos sociais, nas diferentes comunidades e culturas, deixando também de lado a oposição emissor todo-poderoso versus receptor passivo ou, por outro lado, emissor neutro versus receptor/consumidor todo-poderoso. Critica as posturas que se revelam ao mesmo tempo apocalíticas e integradas na análise do poder dos meios de comunicação $e$ defende a quebra da eficácia informacional pelo resgate da cultura, pela democratização da posse dos veículos de comunicação. Aborda a comunicação como processo de mediações sociais e culturais. Conclui situando a escola como mediadora social, principalmente em relação aos meios de comunicação, o que the confere grande importância no processo de recpção.

Palavras-chave: mediações, escola, estudos de recepção, cultura, sujeito
Abstract: The author proposes thinking communication from reception in order to better understand the role of the means of communication in contemporary society's life, how they work on social group day-to-day life, in the different communities and cultures, also leaving to the side the all-powerful emitter opposition versus passive receptor or, on the other hand, neutral emitter versus all-powerful receptor/consumer. It criticizes the posture that reveals to be both apocalyptic and integrated in the analysis of the power of the means of communication and defends the break of international efficacy by recovering culture, by democratizing the ownership of the means of communication vehicles. It considers communication as a social and cultural mediation process. The article concludes situating the school as a social mediator, especially relative to the means of communication, which gives great importance to the reception process.

Key words: mediation, school, reception studies, culture, subject 